\title{
Introduction: Issues and Perspectives on the Dialectics of Knowledge
}

\author{
Bharath Sriraman
}

Published online: 12 March 2013

(C) Springer Science+Business Media Dordrecht 2013

This special issue of Interchange examines both fundamental questions as they pertain to Knowledge, its transmission, transformation, growth and commodification. The last of these constructs "commodification" applies to institutions and other structures within the private sector, that market Knowledge in exchange for tuition dollars and/or institutional fees, with the promise of a degree, diploma, or certificate that may or may not guarantee employment. In many of the "former" socialist countries of Western and Northern Europe where tuition is not a requirement but modest fees are, even a small increment in fees were the cause of student protests (e.g., Germany). This is an interesting dialectic when compared to the university system in the United States, where barring circumstances of scholarships, most students pay for their education (Knowledge acquisition) with tuition dollars, which in turn leads the inquisitive mind into the corporate structures that govern and dole out the tuition dollars in the form of loans and other schemes. This is also true in many Asian countries in which after school prep programs, private tutors, and magnate schools with labels such as La Martiniere, British International, Canadian International, and so forth, attract significant parent incomes with the hope of helping their children navigate the Darwinian system in place. In fact the Asian market is so "open" now in terms of the human population with disposable income that many prominent universities have set up satellite campuses in China, India, and other places. Again the commodity under transaction is "Knowledge" in the form of a degree carrying a coat of arms from some former colonizer. I hope the irony of this is not lost on the reader.

On the other hand, the ideal that all "Knowledge" should be transmitted free or mimic the models in several "former" socialist countries of Europe also runs into issues, namely the abuse of a system that is inherently free which requires the system to levy charges and impose rules to curtail the misuse. So are we in a

B. Sriraman $(\square)$

Department of Mathematical Sciences, The University of Montana, Missoula, MT 59812, USA

e-mail: sriramanb@mso.umt.edu; b_sriraman@yahoo.com 
catch-22 situation here? The astute reader may point to some flaws either in the economic models in place which victimize some economic theory (Smithian, Hamiltonian, Marxist, Keynesian, etc.) or allude to some political theory that can explain why things stand the way they do. As Francis Bacon (1561-1626) pointed out a long time ago, Knowledge is Power, and today we see the effects of the statement in terms of the monetary payouts of having specialized knowledge. This includes Institutions that house schools of medical research, genetics, biochemistry, engineering design, and so forth, where patent generation and product development are emphasized and rewarded in terms of academic promotions and salary. An erudite philosophical or historical treatise on the effects of such research on humanity may very well be punished with the denial of tenure. An ageing philosopher colleague in Troms $\varnothing$ lamented that there used to be a time when academic institutions used to emphasize erudition in their glossy handouts for visitors to campuses, and one found monetary sponsorships and grant monies as a footnote at the very end. Today the opposite is true, erudition is relegated to the footnotes and dollar amounts figure prominently on the front pages. The fact of the matter is that many institutions have bought into the corporate models in place that maximize revenue and minimize the compensation of faculty, staff, and other institutional employees. Where does one see the student in such a scheme-one Marxist analogy may be the "worker" caught in the giant cogs of Industrialization, the other Capitalist analogy may be the "client" that is being catered to (or exploited?). Where does one see a faculty in such a scheme especially if all their training and research is only hinged on the use of sponsorships (Government, private or otherwise)? On the other hand can one blame Institutions for eliminating faculty for their scholarly indolence? An example that comes to mind is those that wax philosophical about social reform and activism, yet their own indolence in terms of transforming this into scholarship results in unfavorable outcomes but then they can resort to playing the victim of the very system they are criticizing. Barring such vicissitudes, we in general live in an era where the Humanities are on the receiving end of budget cuts simply because erudition is no longer valued, neither by the institutions, nor the students, whose dwindling numbers are used to justify such cuts by Institutions (Woodhouse 2009). The interested reader may want to examine as well as a gem that I recently discovered in India, John Ruskin's (1862) Unto this Last, which presents a compelling account of individual and Institutional accountability (economic, educational, political) and seems relevant 150 years later. Similarly the writings of C.S. Lewis that have nothing to do with "Narnia" have a relevant voice in our present situation.

This issue of Interchange contains a very interesting selection of papers, some of which I have had the pleasure of co-writing. There are also some strands of continuity with a previous issue 42/2 (Sriraman and Fyhn 2011). There are numerous voices present such as the need to impose a framework for quality assurance in the globalization of higher education (Job and Sriraman), Eastern and Indigenous learning traditions that do not fit into the dictates of westernized institutional knowledge but nevertheless have a long traditions, for example, Advaita-Vedanta from India (Sriraman and Benesch), Inuit legends and oral histories (MacMillan), Confucianism and its intersection with the dogma of Constructivism (Lee and Sriraman), and the 
need to reintegrate humanism into education (Seung Chun Lee; Liang and Han). Taken together as a whole, the papers emphasize other ways of learning and teaching such as the use of culturally based or narrative based learning (namely the transmission and transformation of Knowledge), the problematique in the ad-hoc imposition of western models of academia (namely the dialectic in institutional growth and commodification), and the need to examine humanism—and its various forms.

\section{References}

Ruskin, J. (1862). Unto this Last. Retrieved from http://muff.uffs.net/skola/dejum/ruskin/texts/unto-thislast/unto_this_last.pdf. Accessed 4 Jan 2013.

Sriraman, B., \& Fyhn, A. B. (2011). Circumpolar indigenous issues, knowledge, relation to education, science and mathematics. Interchange, 42(2), 99-219.

Woodhouse, H. (2009). Selling out: Academic freedom and the corporate market. Montreal: McGillQueen's University Press. 